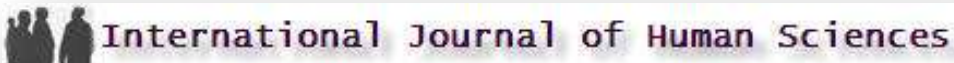

Volume: 11 Issue: 2 Year: 2014

\section{Constraints on leisure time physical activity at a public university}

\author{
Kubilay Öcal ${ }^{1}$
}

\begin{abstract}
This study focuses on understanding constraints on leisure time physical activity (LTPA) on a university campus. The survey study was conducted with public university students $(n=563)$ living in dormitories. The 38-item, 8-dimension Leisure Time Physical Activity Constraints (LTPA-C) Scale was used to investigate factors limiting LTPA. Age, gender, working status (i.e. part-time, non-working), program type (i.e. morning education, evening education), relationship status (i.e. in a relationship, not in a relationship), monthly expenses and body mass index (BMI) category (i.e. underweight, normal weight, overweight, obese) are key variables believed to affect LTPA-C. An initial confirmatory factor analysis was conducted to validate the structure of the scale, and frequency analysis, Pearson's Correlation and t-tests were conducted to analyze the survey responses. Results showed the hierarchy of constraints for males (from high to low) to be as follows: society, income, time, facility, willpower, skill perception, family, body perception. The hierarchy was nearly identical for females, except 'willpower' was found to be a greater constraint than 'facility'; moreover, the differences in the rates at which males and females perceived 'facility' and 'willpower' to be constraints were statistically significant.

The study findings indicate that by taking steps to improve the infrastructure of university campus facilities and organize group activities, university management can provide motivation and social support that can help to increase university student participation in LTPA.
\end{abstract}

Keywords: LTPA, Constraint, Negotiation, University Students, Campus.

\section{Introduction}

Research has shown university students to be inactive (Kulavic, Hultquist \& McLester, 2013), with many of them failing to meet the minimum level of physical activity recommended by sport and health science authorities (Egli, Bland, Melton \& Czech, 2011; Gülec, Yabanc1, Gocgeldi \& Bakir, 2008; McArthur \& Raedeke, 2009; Miller, Noland, Rayens \& Staten, 2008; Vancelik, Onal, Güraksin \& Beyhun, 2007). Over time, inactivity leads to a sedentary lifestyle, which increases the risk of cardiovascular disease, Type-2 diabetes, hypertension (Demir \& Filiz, 2004; Sattelmair et al. 2011), stress, depression (Craike, Coleman \& MacMahon, 2010; Karatosun,

\footnotetext{
${ }^{1}$ Assist. Prof. Dr., Mugla S1tk1 Koçman University, School of Physical Education \& Sports, ocalkubilay@gmail.com
} 
Öcal, K. (2014). Constraints on leisure time physical activity at a public university. International Journal of Human Sciences, 11(2), 648-660. doi: 10.14687/ijhs.v11i2.3013

2010) and obesity (Errara, Nobrega \& Dulfan, 2013; Wang et al. 2012; WHO, 2012). Lack of physical activity can also be an important factor in negative body image (Crocker, Major \& Steele, 1998; Silva, Nahas, de Sousa, Del Duca \& Peres, 2011).

According to recent statistics, $45.5 \%$ of individuals in Turkey aged $20-24$ years do not participate in any physical activity (SETA, 2012). Even more alarming, despite the welldocumented benefits of physical activity and the risks associated with a sedentary lifestyle, a report by the Turkish Ministry of Health (2011) found that only 15.5\% of individuals over age 18 participate in physical activities in order to improve their health.

The World Health Organization (2003) has indicated that at least 60\% of the global population fails to meet the minimum recommendations for daily physical activity. In order to achieve a minimum level of physical activity, the American College of Sports Medicine recommends that adults between the ages of 18 and 65 years perform either moderately intense cardiovascular exercise for $\geq 150$ minutes per week ( $\geq 30$ minutes a day, $\geq 5$ days week) or vigorously intense cardiovascular exercise for $\geq 75$ minutes per week ( $\geq 20$ minutes a day, $\geq 3$ days a week). Garber, (2011) and Kulavic et al. (2013) also recommended performing strength-training exercises 2-3 times per week (8-10 exercises, with 8-12 repetitions per exercise).

According to Young, Ross and Barcelona (2003), the lack of participation in physical activity and recreational sport programs may be attributed to a variety of perceived constraints. Although these constraints are highly dependent upon individual perceptions (Crawford, Jackson, \& Godbey, 1991; Daskapan, Tuzun \& Eker, 2006), in general, they can be categorized as constraints on either preferences, participation, or enjoyment Jackson, 2000; Kleiber, McGuire, Aybar-Damali \& Norman, 2008).

Jackson (1988) defined constraints on leisure time activities as either internal - i.e. related to abilities, skills, knowledge and health problems - or external, i.e. related to financial costs and/or lack of time, facilities and transportation. Crawford et al. (1991), on the other hand, lists three types of constraints: interpersonal, intrapersonal and structural. Accordingly, interpersonal constraints are influenced by social relationships; intrapersonal constraints are affected by individual physiological states such as stress, depression, anxiety, subjective assessment of sustainability and availability of leisure activities (Seong, Chi-Ok \& Hoon, 2013); and structural constraints are affected by external factors such as financial restrictions and lack of time, transportation or awareness that intervene between leisure preferences and participation (Taylor \& Doherty, 2005; Tsai \& Coleman, 2009). 
Öcal, K. (2014). Constraints on leisure time physical activity at a public university. International Journal of Human Sciences, 11(2), 648-660. doi: 10.14687/ijhs.v11i2.3013

\section{Purpose of the study}

Establishing an active lifestyle is an important prerequisite for reaping the social, physiological and physical benefits of LTPA. In order to ensure the sustainability of LTPA participation, it may be necessary to first overcome a number of problems and limitations (Öcal, 2012). Research indicates that the more physically active adolescents and young adults are in their leisure time, the more likely they are to remain active throughout their lifespan (Hashem, Akbar, Ali, \& Masume, 2012). A review study by Shifman, Moss, D'Andrade, Eichel and Forrester (2011) identified relatively few studies examining constraints on university students' participation in recreational sports. Therefore, the present study aimed to provide information regarding constraints on LTPA participation among male and female university students living in student dormitories.

\section{Theoretical Perspective}

Leisure constraints and negotiation strategies are two inseparable concepts that have been the focus of research for several decades (Godbey, Crawford, \& Shen, 2010). Leisure participation is strongly dependent upon the capacity to negotiate with various constraints. According to Crawford and Godbey (1987), constraints are independent and follow a hierarchy or continuum model from most proximal to most distal; of the three types of constraints (intrapersonal, interpersonal, structurl), intrapersonal constraints are the most powerful and structural constraints are the least powerful. Jackson, Crawford and Godbey (1993) expanded on this hierarchical model of leisure constraints by introducing the role of motivation as a mediator between constraints and successful negotiations. Later, Hubbard and Mannell (2001) examined the relationship between constraints, negotiation and physically active leisure time by tested four alternative models: 'independence', 'negotiation-buffer', 'perceived constraint-reduction' and 'constraint-effects-mitigation'. The latter model, which has been supported by numerous studies (Hubbard \& Mannell, 2001; Son, Mowen, \& Kerstetter, 2008), suggests that individuals have the ability to modify their actions when faced with constraints in order to maintain their participation in leisure activity through negotiation. According to social-cognitive theory (Bandura and Adams, 1977), the successful use of negotiation strategies is influenced by self-efficacy (Henderson, Bedini, Hecht \& Schuler, 1995; Hubbard \& Mannell, 2001; Loucks-Atkinson \& Mannell, 2007; Dimmock \& Wilson, 2011), an important psychological component that involves the belief that one can successfully exert control over challenging conditions (Bandura, 2004). Thus, belief in one's ability to negotiate constraints can provide an advantage when struggling with difficulties in terms of planning, organizing and participating in LTPA. 
Öcal, K. (2014). Constraints on leisure time physical activity at a public university. International Journal of Human Sciences, 11(2), 648-660. doi: $10.14687 /$ ijhs.v11i2.3013

\section{Methods}

\section{Participants}

This survey study was conducted among a sample of public university students $(\mathrm{n}=563$ ) residing in student dormitories. Data was disaggregated by gender, working status, program type, relationship status and BMI category, with age and monthly expenditures used as continuous variables. Overall, $48.7 \%$ of participants were female and $51.3 \%$ were male, with the age of participants ranging from 17-27 years (mean age: 20.64). Only 5.9\% of participants were employed. The majority (73.5\%) were enrolled in daytime education (09.00-17.00) and the remaining $26.5 \%$ in evening education (17.00-24.00). According to BMI -calculations [mass $(\mathrm{kg}) /$ height $\left.(\mathrm{m})^{2}\right]$, the majority $(73.0 \%)$ of students were of normal weight, whereas $10.9 \%$ were underweight, $12.8 \%$ were overweight and $1.1 \%$ were obese. The mean total monthly expenditures of participants were 471TL $\pm 297.72 \mathrm{TL}$ (appx. $220 \mathrm{USD}$ ).

Table 1. Demographic profile of participants

\begin{tabular}{|c|c|c|}
\hline & $\mathrm{N}$ & Percent \\
\hline \multicolumn{3}{|l|}{ Gender } \\
\hline Male & 289 & 51.3 \\
\hline Female & 274 & 48.7 \\
\hline \multicolumn{3}{|l|}{ Working Status } \\
\hline Non-Working & 525 & 94.1 \\
\hline Part-Time & 33 & 5.9 \\
\hline \multicolumn{3}{|l|}{ Program Type } \\
\hline Daytime Education & 410 & 73.5 \\
\hline Evening Education & 148 & 26.5 \\
\hline \multicolumn{3}{|l|}{ Relationship Status } \\
\hline In a Relationship & 223 & 40.5 \\
\hline Not in a Relationship & 328 & 59.5 \\
\hline \multicolumn{3}{|l|}{ BMI Category } \\
\hline Underweight & 61 & 10.9 \\
\hline Normal weight & 411 & 73.0 \\
\hline Overweight & 72 & 12.8 \\
\hline Obese & 6 & 1.1 \\
\hline \multicolumn{3}{|l|}{ Age } \\
\hline Min & 17 & \\
\hline $\operatorname{Max}$ & 27 & \\
\hline Mean & 20.64 & \\
\hline $\mathrm{SD}$ & 1.6 & \\
\hline \multicolumn{3}{|l|}{ Monthly Expenditures } \\
\hline Min & 100 & \\
\hline Max & 3000 & \\
\hline Mean & 471 & \\
\hline $\mathrm{SD}$ & 297.72 & \\
\hline
\end{tabular}


Öcal, K. (2014). Constraints on leisure time physical activity at a public university. International Journal of Human Sciences, 11(2), 648-660. doi: $10.14687 /$ ijhs.v11i2.3013

\section{Instruments}

Constraints to physical activities were measured using the Leisure Time Physical Activity Constraints Scale (LTFA-C) developed by Öcal (2012). The scale is comprised of 38 items with 8 dimensions: Body Perception, Facility, Family, Income, Skill Perception, Society, Time and Willpower. The overall scale has an Alpha coefficient of .94. Body Perception Constraints $(\alpha=.92)$ refers to negative feelings regarding one's own body related to anxiety over other people's perceptions; Facility Constraints $(\alpha=.90)$ refers to limits on space and infrastructure appropriate to the nature of any chosen physical activity; Family Constraints $(\alpha=.88)$ refers to limits to support provided by family members for an individual's participation in physical activity; Income Constraints $(\alpha=.92)$ refers to limitations on finances required for participation in physical activity (including purchases of kit/equipment); Skill Perception Constraints $(\alpha=.88)$ refers to fear of failure to adequately perform the movements/techniques required for a physical activity; Society Constraints $(\alpha=$.85) refers to difficulties in finding or meeting up with individual friends or groups in order to participate in physical activity; Time Constraints $(\boldsymbol{\alpha}=.97)$ refers to limitations to leisure time available for participation in physical activity; and Willpower Constraints $(\alpha=.84)$ refers to emotional weaknesses that lead to withdrawal from activity programs. Participants were asked to grade their responses on a 6-point Likert scale ('strongly disagree' (1), 'disagree' (2), 'partially disagree' (3), 'partially agree' (4), 'agree' (5) and 'strongly agree' (6).

\section{Design and procedure}

Participants residing in two different dormitories near the Muğla University campus were asked to complete the LTFA-C scale. Participants were informed that the survey was optional, that they were not required to complete it once they started, and that all their responses would be anonymous and confidential. Data from the collected surveys were entered into the statistical software program SPSS 20 and analyzed using confirmatory factor analysis, frequency analysis, Pearson's Correlation and t-test).

\section{Results}

Confirmatory factor analysis (CFA) was conducted using the Analysis of Moment Structures (AMOS) statistical software package, Version 18 (Arbuckle \& Wothke, 1999) in order to confirm the factor structure of the scale with the collected data. Results of CFA showed perfect $($ RMSEA $=0.04)$ or good $(\mathrm{NFI}, \mathrm{CFI}>0.95)$ fit of the eight-factor structure to the sample data, indicating the usefulness of all of the dimensions of the LTFA-C scale. 

11(2), 648-660. doi: $10.14687 /$ ijhs.v11i2.3013

The relationship between demographic variables and the 8 dimensions of the LTFA-C scale was examined using Pearson's Correlation Analysis (Table 2). All factors of the scale correlated each other significantly at the 0.01 level $(.17 \leq \mathrm{r} \leq .68)$. Additionally table also presented correlation between demographic variable and factors of the scale. In brief, result provides significant correlation between two constraints (i.e. facility, willpower) and gender to be considered.

Table 2 Correlation coefficients of demographic variables and LTFA-C scale dimensions

\begin{tabular}{|c|c|c|c|c|c|c|c|c|c|c|c|c|c|c|c|}
\hline & 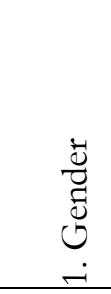 & 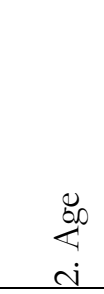 & 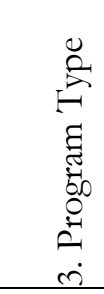 & 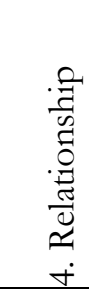 & 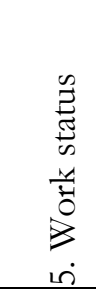 & $\begin{array}{l}\tilde{0} \\
0 \\
0 \\
0 \\
0 \\
0 \\
0 \\
0 \\
0 \\
0 \\
0 \\
0\end{array}$ & 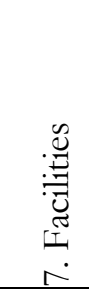 & $\begin{array}{c}\mathscr{\Xi} \\
\tilde{\Xi} \\
\mathscr{G} \\
\infty \\
\infty\end{array}$ & 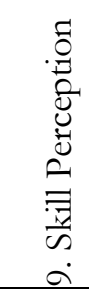 & 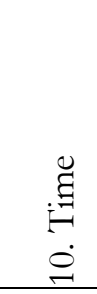 & 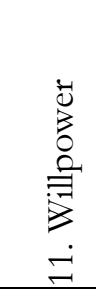 & 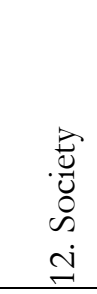 & 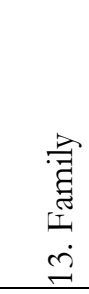 & 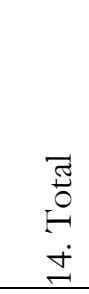 & $\begin{array}{l}\sum_{\infty} \\
\dot{m} \\
\stackrel{n}{n}\end{array}$ \\
\hline \multicolumn{16}{|l|}{1} \\
\hline 2 & $-.16^{* *}$ & & & & & & & & & & & & & & \\
\hline 3 & $-.33^{* *}$ & $.19^{* *}$ & & & & & & & & & & & & & \\
\hline 4 & $.14^{* *}$ & $-.09^{*}$ & -.06 & & & & & & & & & & & & \\
\hline 5 & -.02 & $.13^{* *}$ & .00 & -.03 & & & & & & & & & & & \\
\hline 6 & .05 & -.02 & -.02 & .04 & $.10^{*}$ & & & & & & & & & & \\
\hline 7 & $.11^{*}$ & .02 & -.03 & .05 & -.06 & $.31^{* *}$ & & & & & & & & & \\
\hline 8 & .02 & -.03 & -.00 & -.03 & -.05 & $.18^{* *}$ & $.46^{* *}$ & & & & & & & & \\
\hline 9 & .04 & $-.09^{*}$ & -.00 & .06 & .03 & $.47^{* *}$ & $.32^{* *}$ & $.23^{* *}$ & & & & & & & \\
\hline 10 & -.02 & -.00 & .06 & -.05 & $.11^{*}$ & $.32^{* *}$ & $.32^{* *}$ & $.29^{* *}$ & $.40^{* *}$ & & & & & & \\
\hline 11 & $-.08^{*}$ & -.07 & .02 & .02 & -.03 & $.42^{* *}$ & $.27^{* *}$ & $.22^{* *}$ & $.50^{* *}$ & $.34^{* *}$ & & & & & \\
\hline 12 & -.00 & -.04 & .04 & .04 & -.02 & $.17^{* *}$ & $.43^{* *}$ & $.47^{* *}$ & $.25^{* *}$ & $.25^{* *}$ & $.36^{* *}$ & & & & \\
\hline 13 & .07 & -.09 & .02 & -.04 & .04 & $.39^{* *}$ & $.29^{* *}$ & $.33^{* *}$ & $.42^{* *}$ & $.34^{* *}$ & $.22^{* *}$ & $.18^{* *}$ & & & \\
\hline 14 & .05 & -.08 & -.02 & .02 & .01 & $.62^{* *}$ & $.75^{* *}$ & $.68^{* *}$ & $.67^{* *}$ & $.59^{* *}$ & $.63^{* *}$ & $.64^{* *}$ & $.59^{* *}$ & & \\
\hline 15 & $.23^{* *}$ & .04 & $-.15^{* *}$ & .06 & -.03 & .03. & .04 & .03. & .08 & .01 & .02 & .02 & -.05 & .03 & \\
\hline
\end{tabular}

Figure 1 shows the level of 8 constraints on LTPA according to gender. In general, the mean scores for each constraint are similar for males and females; however, scores for willpower and time constraints were slightly higher for females, whereas scores for skill perception, family, income, facilities and body perception constraints were higher for males. The hierarchy of constraints (from higher to lower) for males is 'society, income, time, facility, willpower, skill perception, family and body perception;' except for a transposition in the roles of 'facility' and 'willpower', the hierarchy of constraints is identical for females. 
Öcal, K. (2014). Constraints on leisure time physical activity at a public university. International Journal of Human Sciences, 11(2), 648-660. doi: $10.14687 /$ ijhs.v11i2.3013

Figure 1. Mean scores for 8 LTPA constraints, by gender.

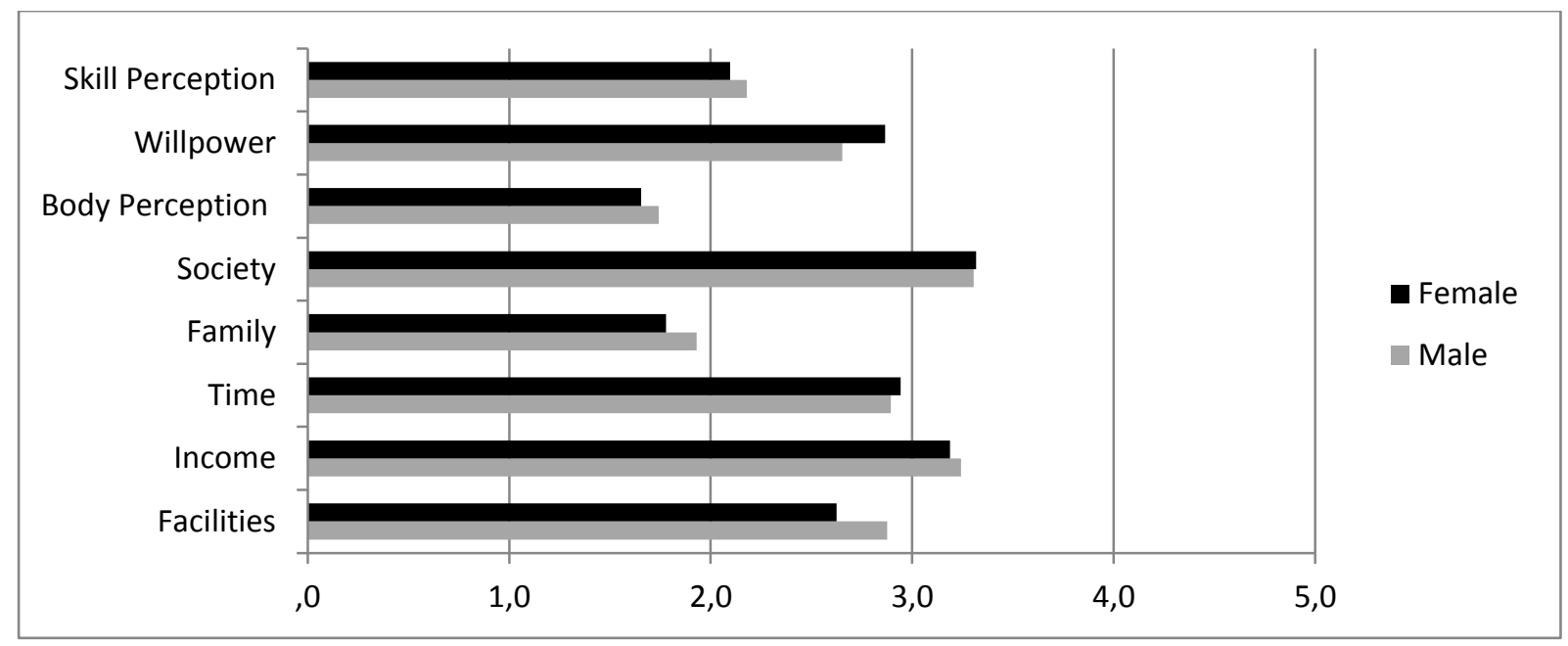

Figure 2. Mean scores for 3-constraint (intrapersonal/interpersonal/structural) model, by gender.

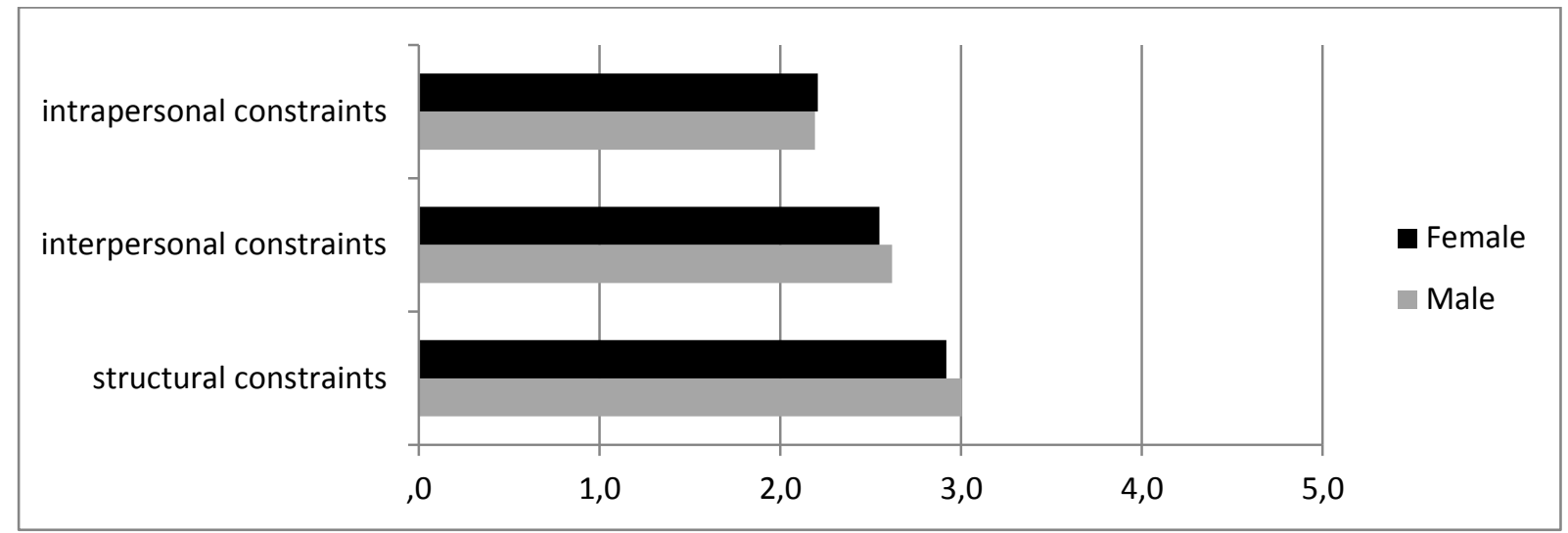

Figure 2 shows the level of constraints for gender in terms of Crawford and Godbey's (1987) 3-constraint model. Accordingly, structural constraints were found to be most influential, followed by intrapersonal constraints and interpersonal constraints.

An independent sample t-test was used to examine the significance of differences between scores of male and female study participants (Table 3). Among the LTPA-C scale factors, only the differences in scores for 'facility' [ $\mathrm{t}$ (522) $=2.57, \mathrm{p}=.011$ ] and 'willpower' [ $\mathrm{t}$ (550) $=1.97, \mathrm{p}=.049]$ were found to vary significantly between males and females.

Table 3. Differences in LTPA constraints, by gender ( $\mathrm{T}$-test results)

\begin{tabular}{llllllll}
\hline Constraint & Gender & $\mathrm{N}$ & mean & $\mathrm{sd}$ & $\mathrm{Df}$ & $\mathrm{t}$ & $\mathrm{p}$ \\
\hline Facility & Female & 262 & 2.624 & 1.041 & 522 & 2.567 & .011 \\
& Male & 262 & 2.876 & 1.199 & & & \\
\cline { 2 - 7 } Willpower & Female & 269 & 2.866 & 1.188 & 550 & 1.977 & .049 \\
& Male & 283 & 2.652 & 1.337 & & & \\
\hline
\end{tabular}


Öcal, K. (2014). Constraints on leisure time physical activity at a public university. International Journal of Human Sciences, 11(2), 648-660. doi: 10.14687/ijhs.v11i2.3013

\section{Discussion}

Research has shown that the level of physical activity among individuals has dramatically decreased over the past 50 years. This tendency towards a sedentary lifestyle has been supported by a remarkable increase in the service industry that has affected all areas of life, as an understanding that equates inactivity with prosperity motivates us to 'get serviced' to the greatest extent possible. Moreover, with the development of technology, daily activities such as washing dishes and cutting grass can be performed with the aid of machines, thereby preventing us from burning fat and calories ourselves, while multimedia systems, game consoles and home theaters keep us at home and inactive for long hours. Furthermore, increases in automobile use and the growth of online food services have laid the groundwork for growing levels of obesity throughout the world (Fox \& Hillsdon, 2007). Given these negative developments, the responsibility falls on fitness and wellness professionals to increase the level of physical activity among people of all ages in support of national health and wellness. In order to achieve this aim, it is necessary to begin by removing the constraints that limit LTPA in daily life.

This study selected university students as its target population. According to Kulavic et al. (2013), major life adjustments are likely to occur at university. This period in life is characterized by the exploration of numerous alternative experiences, and it is important in the configuration of an active lifestyle that can continue until the end of life. In this challenging environment, sport specialists, university deans and campus recreation managers need to ensure that university students are provided with an environment that is sufficiently attractive to win them over to the world of sports, recreation and physical activity.

Unfortunately, statistics indicate that the level of physical activity declines with the transition from high school to college (Calfas, Sallis \& Lovato, 1994; Kilpatrick, Hebert \& Bartholomew, 2005) due to changes in individual roles and relationships and environmental contexts (Raymore, Barber \& Eccles, 2001). For many students, major life stressors prompt changes in leisure behavior and are associated with decreases in physical activity (Resnicow et al. 1998). According to the findings of the present study, the reasons for this decline are fairly consistent for males and females, with society, income and time constraints representing the most significant factors limiting LTPA. These are followed by facility and willpower for males, and by willpower and facility for females. Finally, skill perception, family and body perception are at the bottom of the hierarchy of constraints for both females and males. In the case of this study, 'society' as a constraint refers to limitations on individual or groups of friends with whom students can participate in activities. This finding is of particular concern, considering that the students who participated in this study live in dormitories on or close to a university campus with 
Öcal, K. (2014). Constraints on leisure time physical activity at a public university. International Journal of Human Sciences, 11(2), 648-660. doi: 10.14687/ijhs.v11i2.3013

easy access to a variety of LTPA facilities. It is also important in that it reflects a general perspective among society, or at least among university members, regarding participation in physical activity. Clearly, although LTPA participation should be a habit that starts at home and is developed in schools, this system is not functioning smoothly in Turkey.

A study by Crawford and Godbey (1987) found that of the 3 types of constraints on LTPA (interpersonal, intrapersonal and structural), intrapersonal constraints were the most powerful and structural constraints the least powerful. While the present study found the mean score for structural constraints to be higher than those of the other constraints examined, in fact, it may be that intrapersonal constraints act as triggers that increase the structural constraints on LTPA participation among university students. Intrapersonal constraints affect our general perceptions and capacity for negotiation; thus, a small decrease in intrapersonal constraints could provide significant motivation, increasing the ability of students to negotiate huge amounts of structural constraints, thereby increasing participation levels.

The results of this study partially supported the hypothesis that constraints on LTPA differ according to gender. Differences were found in the factors of 'facility' and 'willpower', with 'facility', surprisingly, found to be a greater constraint for male than for female university students. There are 2 possible explanations for this finding. First of all, in comparison to females, males tend to be more involved in physical activities (Olds et.al. 2009; Riddoch et al. 2007) and to spend more time in activity-enhancing environments (Bailey, Wellard \& Dismore, 2004); thus, they would be more affected by a lack of or limited infrastructure and facilities. Second of all, Azevedo (2007) state that moderate-intensity, vigorous-intensity and total leisure-time physical activity practices are all higher among men than women. In contrast, Abel, Graf and Niemann (2001) state that females are more likely to perform daily walking and biking activities. Given their involvement in a greater variety of physical activities in comparison to females, males could be expected to experience a greater level and variety of constraints.

With regard to a gender gap in terms of willpower as a constraint, studies by Ainsworth, Wilcox, Thompson, Richter and Henderson (2003) and Kulavic et al (2013) also identified lack of willpower as an important barrier to be overcome, and studies by Saxena, Borzekowski and Rickert (2002) and Robbins, Pender and Kazanis (2003) specifically identified lack of motivation and laziness as factors preventing adolescent girls from participating in physical activities. These findings support the result of the present study. Other studies (Fukuoka, Vittinghoff, Jong \& Haskell, 2010; Rye, Rye, Tessaro \& Coffindaffer, 2009; Vilhjalmsson \& Kristjansdottir, 2003) have noted that girls are more likely to withdraw from exercise than boys. According to Stewart 
Öcal, K. (2014). Constraints on leisure time physical activity at a public university. International Journal of Human Sciences, 11(2), 648-660. doi: 10.14687/ijhs.v11i2.3013

and Taylor (2000), negative experiences were the main reasons why females withdraw from or demonstrate low levels of participation in physical activities.

Increasing LTPA participation in and around university campuses are primarily the responsibility of university administrators and local governments. Improving infrastructural conditions of on-campus facilities and organizing group activities in order to provide social support represent a logical first step towards increasing the motivation of university students for participating in LTPA.

\section{Limitations and future directions}

This study is limited to a population of 532 participants attending a public university. Future studies can be conducted to compare populations at both public and private universities as well as cross-cultural populations. While this study is a quantitative study that examined 38 items related to 8 constraining factors, additional qualitative studies may provide a deeper understanding of LTPA constraints among university students, including the relationship between PA levels and constraints. Moreover, a next step should concentrate on developing ways to limit the effects of these constraints by either intervening in the PA environment or raising awareness among university students about the problems of inactivity.

\section{References}

Abel, T., Graf, N., \& Niemann, S. (2001). Gender bias in the assessment of physical activity in population studies. Soz Praventiv Med 46: 268-72.

Ainsworth, B. E., Wilcox, S., Thompson, W. W., Richter, D. L., \& Henderson, K. A. (2003). Personal, social, and physical environmental correlates of physical activity in AfricanAmerican women in South Carolina. American Journal of Preventive Medicine, 25(3), 23-29.

Arbuckle, J. L., \& Wothke, W. (1999). Amos 4.0 user's guide. Chicago, IL: SPSS.

Azevedo, M. R., Araújo, C. L. P., Reichert, F. F., Siqueira, F. V., da Silva, M. C., \& Hallal, P. C. (2007). Gender differences in leisure-time physical activity. International Journal of Public Health, 52(1), 8-15.

Bailey, R., Wellard, I., \& Dismore, H. (2004). Girls' participation in physical activities and sports: Benefits, patterns, influences and ways forward. Centre for Physical Education and Sport Research. United Kingdom: Canterbury Christ Church University College. Available from http:/ / wnw. icsspe. org/portal/download/Girls. pdf.

Bandura, A. (2004). Health promotion by social cognitive means. Health education \& behavior, 31(2), 143-164.

Bandura, A., \& Adams, N. E. (1977). Analysis of self-efficacy theory of behavioral change. Cognitive therapy and research, 1(4), 287-310.

Baranowski, T., Thompson, W. DuRant, R., Baranowski, J. and Puhl, J. (1993). Observations on Physical Activity in Physical Locations: age, gender, ethnicity, and month-effects. Research Quarterly for Exercise and Sport, 64(2),127-133.

Buckworth, J., \& Nigg, C. (2004). Physical activity, exercise, and sedentary behavior in college students. Journal of American College Health, 53(1), 28-34. 
Öcal, K. (2014). Constraints on leisure time physical activity at a public university. International Journal of Human Sciences, 11(2), 648-660. doi: 10.14687/ijhs.v11i2.3013

Butler, S.M., Black, D.R., Blue, C.L., \& Gretebeck, R.J. (2004). Change in diet, physical activity, and body weight in female college freshman. American Journal of Health Behavior, 28(1), $24-32$.

Calfas, K. J., Sallis, J. F., Lovato, C. Y. (1994). Campbell J. Physical activity and its determinants before and after college graduation. Medicine, Exercise, Nutrition \& Health, 3, 323-334

Crawford, D. W., Jackson, E. L., \& Godbey, G. (1991). A hierarchical model of leisure constraints. Leisure sciences, 13(4), 309-320.

Crawford, D., \& Godbey, G. (1987). Reconceptualizing barriers to family leisure. Leisure Sciences, 9, 119-127.

Craike, M., Coleman, D., \& MacMahon, C. (2010). Direct and Buffering Effects of Physical Activity on Stress-Related Depression in Mothers of Infants. Journal Of Sport \& Exercise Psychology, 32(1), 23-38.

Crocker, J., Major, B., \& Steele, C. (1998). Social stigma. In D. Gilbert, S. T. Fiske, \& G. Lindzey (Eds.), The handbook of social psychology (4th ed., Vol. 2, pp. 504-553). New York: McGraw Hill.

Daskapan, A., Tuzun, E.H., \& Eker, L. (2006). Perceived barriers to physical activity in university students. Journal of Sports, Science, and Medicine, 5, 615-620.

Day, K., Alfonzo, M., Chen, Y., Guo, Z., \& Lee, K. K. (2013). Overweight, obesity, and inactivity and urban design in rapidly growing Chinese cities. Health \& place, 21, 29-38.

Demir, M, Filiz, K. (2004). Spor egzersizlerinin insan organizması üzerindeki etkileri. Gazi Üniversitesi Kirşehir Ë̆itim Fakültesi, 5(2), 109-114.

Dimmock, K., \& Wilson, E. (2011). "Take a deep breath": How recreational scuba divers negotiate in-water constraints. Leisure/Loisir, 35, 283-297

Egli, T., Bland, H.W., Melton, B.F., \& Czech, D.R. (2011). Influence of age, sex, and race on college students' motivation of physical activity. Journal of American College Health, 59(5), 399-406.

Errara, C. M., Nobrega, C., \& Dulfan, F. (2013). Obesity, diet, and physical activity behaviors of students in health-related professions. College student journal, 47(3), 560-565.

Fox KR, Hillsdon M. (2007). Physical activity and obesity. Obesity Reviews, 8 (1), 115-121.

Fukuoka, Y., Vittinghoff, E., Jong, S. S., \& Haskell, W. (2010). Innovation to motivation pilot study of a mobile phone intervention to increase physical activity among sedentary women. Preventive medicine, 51(3), 287-289.

Garber, C. E., Blissmer, B., Deschenes, M. R., Franklin, B. A., Lamonte, M. J., Lee, I. M., ... \& Swain, D. P. (2011). American College of Sports Medicine position stand. Quantity and quality of exercise for developing and maintaining cardiorespiratory, musculoskeletal, and neuromotor fitness in apparently healthy adults: guidance for prescribing exercise. Medicine and Science in Sports and Exercise, 43(7), 1334-1359.

Güleç, M., Yabancı, N., Göçgeldi, E., \& Bakır, B. (2008). Ankara'da iki kız öğrenci yurdunda kalan öğrencilerin beslenme alıskanlıkları. Gülhane Thp Dergisi, 50, 102-109.

Godbey, G., Crawford, D. W., \& Shen, X. S. (2010). Assessing hierarchical leisure constraints theory after two decades. Journal of Leisure Research, 42(1), 111-134.

Henderson, K. A., Bedini, L. A., Hecht, L., \& Schuler, R. (1995). Women with physical disabilities and the negotiation of leisure constraints. Leisure Sciences, 14(1), 17-31.

Hashem, K., Akbar, H., Ali, S., \& Masume, H. (2012). Campus Recreation Worldwide: A Literature Review. International Journal Of Academic Research In Business And Social Sciences, (04), 132.

Haskell, W. L., Lee, I. M., Pate, R. R., Powell, K. E., Blair, S. N., Franklin, B. A., ... \& Bauman, A. (2007). Physical activity and public health: updated recommendation for adults from the American College of Sports Medicine and the American Heart Association. Circulation, $116(9), 1081$. 
Öcal, K. (2014). Constraints on leisure time physical activity at a public university. International Journal of Human Sciences, 11(2), 648-660. doi: 10.14687/ijhs.v11i2.3013

Hubbard, J. \& Mannell, R. C. (2001). Testing competing models of the leisure constraint negotiationprocess in a corporate employee recreation setting. Leisure Sciences, 23(3), 145163.

Jackson, E. (1988). Leisure constraints: A survey of past research. Leisure Sciences, 10, 203-215.

Jackson, E. L. (2000). Will research on leisure constraints still be relevant in the twenty-first century? Journal of Leisure Research, 32, 62-68.

Jackson, E., Crawford, D., \& Godbey, G. (1993). Negotiation of leisure constraints. Leisure Sciences, 15, 1-11.

Karatosun, H. (2010). Fiziksel Aktivite ve Ruh Sağlığı. Süleyman Demirel Üniversitesi Yaşam Dergisi, 2(2), 09-13.

Kilpatrick, M., Hebert, E., \& Bartholomew, J. (2005). College students' motivation for physical activity: differentiating men's and women's motives for sport participation and exercise. Journal of American college bealth, 54(2), 87-94.

Kleiber, D., McGuire, F. A., Aybar-Damali, B., \& Norman, W. (2008). Having more by doing less: The paradox of leisure constraints in later life. Journal of Leisure Research, 40, 343-359.

Kulavic, K., Cherilyn, Hultquist, C., \& McLester, J. R. (2013). A comparison of motivational factors and barriers to physical activity among traditional versus nontraditional college students. Journal of American College Health, 61:2, 60-66. DOI: 10.1080/07448481.2012.753890

Loucks-Atkinson, A., \& Mannell, R. C. (2007). Role of self-efficacy in the constraints negotiation process: The case of individuals with fibromyalgia syndrome. Leisure Sciences, 29, 19-36.

McArthur, L. H., \& Raedeke, T.D. (2009). Race and sex differences in college student physical activity correlates. American Journal of Health Behavior, 33(1), 80-90.

Miller, K. H., Noland, M., Rayens, M. K., \& Staten, R. (2008). Characteristics of users and nonusers of a campus recreation center. Recreational Sports Journal, 32, 87-96.

Öcal, K. (2012) Developing a Scale: Leisure Time Physical Activity Constraints (LTPA-C). Hacettepe J. of Sport Sciences, 23 (2), 50-60.

Oh, H. C., Ozturk, M. A., \& Kozub, F. M. (2004). Physical activity and social engagement patterns during physical education of youth with visual impairments. RE: view: Rebabilitation and Education for Blindness and Visual Impairment, 36(1), 39-48.

Olds, T., Wake, M., Patton, G., Ridley, K., Waters, E., Williams, J., \& Hesketh, K. (2009). How do school-day activity patterns differ with age and gender across adolescence? Journal of adolescent health, 44(1), 64-72.

Petosa, R. L., Suminski, R., \& Hortz, B. (2003). Predicting vigorous physical activity using social cognitive theory. American Journal of Health Behavior, 27(4), 301-310.

Raymore, L. A., Barber, B. L., \& Eccles, J. S. (2001). Leaving home, attending college, partnership and parenthood: The role of life transition events in leisure pattern stability from adolescence to young adulthood. Journal of Youth and Adolescence, 30(2), 197-223.

Resnicow, K., Davis, M., Smith, M., Lazarus-Yaroch, A., Baranowski, T., Baranowski, J., ... \& Wang, D. T. (1998). How best to measure implementation of school health curricula: a comparison of three measures. Health Education Research, 13(2), 239-250.

Riddoch, C. J., Mattocks, C., Deere, K., Saunders, J., Kirkby, J., Tilling, K., ... \& Ness, A. R. (2007). Objective measurement of levels and patterns of physical activity. Archives of disease in childhood, 92(11), 963-969.

Robbins, L. B., Pender, N. J., \& Kazanis, A. S. (2003). Barriers to physical activity perceived by adolescent girls. Journal of Midwifery \& Women's Health, 48, 206-212.

Rye, J. A., Rye, S. L., Tessaro, I., \& Coffindaffer, J. (2009). Perceived barriers to physical activity according to stage of change and body mass index in the West Virginia Wisewoman population. Women's Health Issues, 19(2), 126-134. 
Öcal, K. (2014). Constraints on leisure time physical activity at a public university. International Journal of Human Sciences, 11(2), 648-660. doi: 10.14687/ijhs.v11i2.3013

Sattelmair, J., Pertman, J., Ding, E. L., Kohl, H. W., Haskell, W., \& Lee, I. M. (2011). Dose response between physical activity and risk of coronary heart disease a meta-analysis. Circulation, 124(7), 789-795.

Saxena, R., Borzekowski, D.L. G., \& Rickert, V. I. (2002). Physical activity levels among urban adolescent females. Journal of Pediatric and Adolescent Gynecology, 15, 279-284.

Seong Ok, L., Chi-Ok, O., \& Hoon, L. (2013). The Influence of Extraversion on Leisure Constraints Negotiation Process. Journal of Leisure Research, 45(2), 233-252.

SETA (Siyaset, Ekonomi ve Toplum Araștırmalar1 Vakfi) (2012). Youth Profile of Turkey. Pelin Ofset, Ankara.

Shifman, R., Moss, K. D’Andrade, G., Eichel, J., Forrester, S. (2011).A comparison of constraints to participation in intramural sports between international and non- international students. Recreational Sports Journal, 36, 2-12.

Silva, D. A. S., Nahas, M. V., de Sousa, T. F., Del Duca, G. F., \& Peres, K. G. (2011). Prevalence and associated factors with body image dissatisfaction among adults in southern Brazil: a population-based study. Body Image, 8(4), 427-431.

Son, J. S., Mowen, A. J., \& Kerstetter, D. L. (2008). Testing alternative leisure constraint negotiation models: An extension of Hubbard and Mannell's study. Leisure Sciences, 30, 198-216.

Stewart, C., \& Taylor, J. (2000). Why female athletes quit: Implications for coach education. The Physical Educator, 57(4), 170-174.

Taylor, T. \& Doherty, A. (2005). Adolescent sport, recreation and physical education: experiences of recent arrivals to Canada. Sport Education and Society, 10, 211-238.

Telama, R. I. S. T. O., \& Yang, X. (2000). Decline of physical activity from youth to young adulthood in Finland. Medicine and Science in Sports and Exercise, 32(9), 1617-1622.

Tsai, E. H., \& Coleman, D. J. (2009). The influence of constraints and self-efficacies on participation in regular active recreation. Leisure Sciences, 31, 364-383. DOI: 10.1080/01490400902988309

Turkish Ministry of Health (2011). Türkiye Sağllkh Beslenme ve Hareketli Hayat Programı 2010-2014. Kuban Matbaacilik Yayıncilık, Ankara.

Turkish Ministry of Health (2013). Health Statistics Annual 2012. Sentez Matbaacillk ve Yayınc1lik, Ankara.

Vançelik, S., Önal, S. G., Güraksın, A., \& Beyhun, E. (2007). Üniversite öğrencilerinin beslenme bilgi ve alışkanlıkları ile ilişkili faktörler. TSK Koruyucu Hekimlik. Bülteni, 6(4), 242-248.

VanKim, N. A., \& Nelson, T. F. (2013). Vigorous physical activity, mental health, perceived stress, and socializing among college students. American Journal of Health Promotion, 28(1), 7-15.

Vilhjalmsson, R., \& Kristjansdottir, G. (2003). Gender differences in physical activity in older children and adolescents: the central role of organized sport. Social Science and Medicine, 56(2), 363-374.

Wang, D., Zheng, W., Wang, S., Wang, J., Wei, W., Liang, H., \& ... Boffetta, P. (2012). Estimation of cancer incidence and mortality attributable to overweight, obesity, and physical inactivity in china. Nutrition \& Cancer, 64(1), 48-56. DOI: 10.1080/01635581.2012.630166

WHO (World Health Organization). (2003). Physical activity. Retrieved from: http:// www.who.int topics/physical activity.

Young, S. J., Ross, C. M., \& Barcelona, R. J. (2003). Perceived constraints by college students to participation in campus recreational sports programs. Recreational Sports Journal, 27, 47-62. 